Florida International University

FIU Digital Commons

Department of Civil and Environmental

Engineering Faculty Publications

7-6-2019

\title{
Bridging the Gap between Academia and Practice: Project-Based Class for Prestressed Concrete Applications
}

Islam M. Mantawy

Conner Rusch

Sushil Ghimire

Lucas Lantz

Hari Dhamala

See next page for additional authors

Follow this and additional works at: https://digitalcommons.fiu.edu/cee_fac

Part of the Engineering Commons

This work is brought to you for free and open access by the College of Engineering and Computing at FIU Digital Commons. It has been accepted for inclusion in Department of Civil and Environmental Engineering Faculty Publications by an authorized administrator of FIU Digital Commons. For more information, please contact dcc@fiu.edu. 


\section{Authors}

Islam M. Mantawy, Conner Rusch, Sushil Ghimire, Lucas Lantz, Hari Dhamala, Bipesh Shrestha, Anthony Lampert, Mohit Khadka, Anima Bista, Rhytham Soni, Abdulu Saleem Shaik, Eric Lujan, Mika Boyd, Richard Pickings, and Alexander Mabrich 
Article

\title{
Bridging the Gap between Academia and Practice: Project-Based Class for Prestressed Concrete Applications
}

\author{
Islam M. Mantawy ${ }^{1, *(\mathbb{D})}$, Conner Rusch ${ }^{2}$, Sushil Ghimire ${ }^{2}$, Lucas Lantz ${ }^{2}$, Hari Dhamala ${ }^{2}$, \\ Bipesh Shrestha ${ }^{2}$, Anthony Lampert ${ }^{2}$, Mohit Khadka ${ }^{2}$, Anima Bista ${ }^{2}$, Rhytham Soni ${ }^{2}$, \\ Abdulu Saleem Shaik ${ }^{2}$, Eric Lujan ${ }^{2}$, Mika Boyd ${ }^{2}$, Richard Pickings ${ }^{3}$ and Alexander Mabrich ${ }^{4}$ \\ 1 Department of Civil and Environmental Engineering, Florida International University, Miami, FL 33174, USA \\ 2 Department of Civil, Construction and Environmental Engineering, University of New Mexico, \\ Albuquerque, NM 87131-0001, USA \\ 3 BridgeSight, Tahoe, CA 96150, USA \\ 4 Bentley Systems, Sunrise, FL 33326, USA \\ * Correspondence: imantawy@fiu.edu; Tel.: +1-305-348-0110
}

Received: 4 June 2019; Accepted: 3 July 2019; Published: 6 July 2019

\begin{abstract}
Educational approaches in structural engineering have focused on classical methods for solving problems with manual calculations through assignments, quizzes, and exams. The use of computational software to apply the learned knowledge has been ignored for decades. This paper describes an educational approach to tackle the lack of applicable practical exercises in the structural engineering class "CE 506-Prestressed Concrete" at a university in the western United States during the spring of 2017. The class was designed to provide students with the theoretical concepts of prestressed concrete and the ability to interpret applicable design codes. In their project, students continued to build this knowledge by designing a prestressed bridge superstructure according to a unique state design manual. Students prepared a literature review of their selected state in the U.S.A. and used commercial software to perform an analysis and design of their bridge. Additionally, students were asked to backcheck their design using theoretical methods through manual calculations. By the end of the class, students presented their projects in a head-to-head presentation format, to contrast the differences between their designs in a competitive style. This paper summarizes the class structure, the outcome of the design project, and recommendations for future applications of computer technology in structural engineering education.
\end{abstract}

Keywords: Prestressed concrete; Academia-to-industry; Structural engineering software; Project-based learning; Problem-based learning

\section{Introduction}

In 2013, the Structural Engineering Institute (SEI) published "A Vision for the Future of Structural Engineering and Structural Engineers: A Case for Change" [1]. The objective of this vision publication is to provide a strategic plan for professional engineers through 2033. The publication includes the role of education in the formation of future structural engineers. One of the strategic issues is listed as "the tools available to structural engineer are rapidly replacing workforces with automation in many tasks traditionally done by structural engineers. This evolution presents an opportunity, if not a mandate, to transform structural engineering education, training, and practice in ways that will foster an enduring and creative profession". The publication states the desired outcomes as exploring and defining what the structural engineering profession should look like for the next generation of structural 
engineers, including the path for education, the gain of practical knowledge, and technological software applications that will be present throughout their career.

The profession of structural engineering, like many others, has endured extraordinary challenges. Today, structural engineers see themselves in less demand because many of the technical tasks that structural engineers used to do are now completed automatically by computers, even overseas [1]. Compounding the lower demand for structural engineers, the educational system has not changed much in the past few decades; therefore, new graduates entering the profession are not ideally prepared to utilize automation [1].

In educational systems, undergraduate and graduate degree programs for engineers drive to grant undergraduate degrees in all academic majors within a period of four years, but the increasing amount of knowledge leaves the student unprepared for current industrial advancement. This evolution has taken place while the profession has become detached from the formal educational process. Nearly two-thirds of senior structural engineers have no knowledge of any academic programs beyond their own personal experience based on a firm leader survey that was conducted by the members of the publication task committee [1]. This disconnect is further exacerbated by the primacy of the research initiatives at top universities which has distanced the research frontier from mainstream professional practice and has left undergraduate curricula largely unchanged for decades [1].

During the spring of 2017, in a prestressed concrete class (CE 506) at a university in the western United States, an attempt was made to bridge the gap between the traditional educational system and the practical profession for structural engineering. The class was designed to provide theoretical knowledge of prestressed concrete and knowledge of current structural engineering design codes in the U.S. such as "Precast-Prestressed Concrete Institute" (PCI 2017) [2], "American Concrete Institute" (ACI 2017-318) [3], and "American Association of State Highway and Transportation Officials" (AASHTO-LRFD 2014) [4].

High demand for structural and bridge engineering is expected in the next decade in order to allow state agencies and the private sector to rate, retrofit, and replace deficient bridges across the United States. Automation will be necessary to complete these tasks (Figure 1 shows the percentage of deficient bridges across the U.S. states). The CE 506 curriculum was designed to fill this knowledge gap. A bridge project had been assigned for each student with a mandate of using one of two well-known commercial software programs and verifying the design of both software programs using hand calculations from theories which were taught in the class.

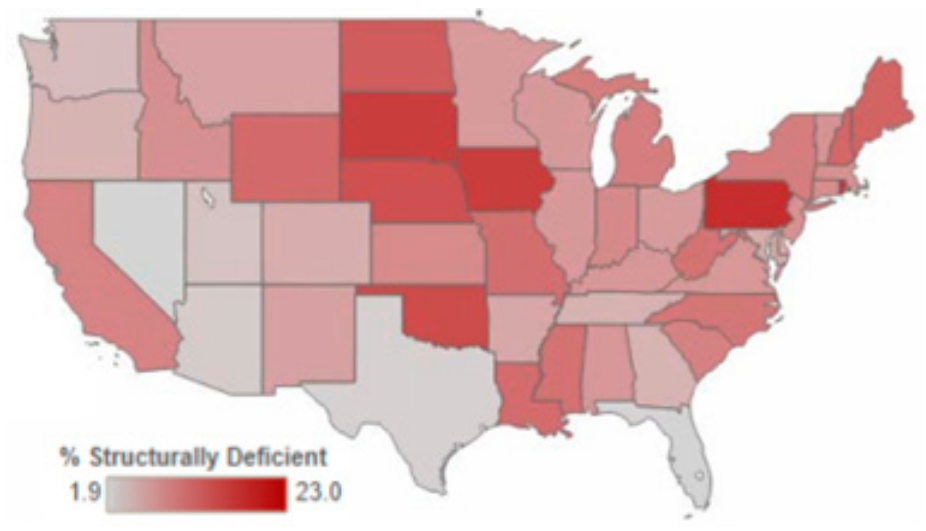

Figure 1. Structural deficiency of U.S. bridges through the states [5].

In order to create a unique learning environment where students and instructor exchange knowledge, each student was asked to select three states where he/she was planning to work after graduation. After the students' selections, a lottery system was utilized to select one U.S. state for each student (a total of 12 states). This paper shows the project setup, development, and outcomes of a total of 12 students in the CE 506 class at a university in the western United States during the spring of 2017. 
To the authors' knowledge, this paper shows the first attempt to utilize the full use of two commercial software programs in a class environment for designing the same structure with differences in U.S. states' requirements, elements sizes, and loading. The students and instructor were able to exchange information about the analysis and design of a structural system in a mutual learning environment, then, students worked collaboratively to prepare their head-to-head presentation for their final project exam in a competitive style.

\section{Literature Review on Problem-Based Learning}

Problem-based learning was defined in Quinn and Albano [6] as active learning in which solving problems provides a context for students to apply their learned knowledge and seek new knowledge. Many instructors have implemented problem-based learning in their classrooms.

Johnson 1999 [7] implemented problem-based learning in a hydraulic engineering class. The instructor designed the class based on a series of projects with a two-week submission interval. Students were placed into groups to complete the assigned projects. Thereafter, student evaluation was utilized to determine the gain of knowledge based on project reports.

Chinowsky et al. 2006 [8] designed a new problem-based learning course for construction management. Instructors arranged and collaborated with the local community to serve as the client, where students worked as construction managers for actual projects under the supervision of the faculty. The faculty had a weekly meeting with students to review their progress and advise them on their future tasks.

WPI 2006 [9] states that project-based learning, which was labelled as the major qualifying project $(\mathrm{MQP})$, was an undergraduate degree requirement at Worcester Polytechnic Institute (WPI) for over 40 years. The purpose of MQP is to allow students to apply their learned knowledge and skills in a real-world problem.

Quinn and Albano 2008 [6] reported one MQP at WPI. The first author worked mutually with another student under the supervision of the second author to study the design of a hospital facility with two design alternatives, including lateral load design for both designs. The first alternative was a structural steel frame and the second one was a reinforced concrete frame. In both alternative designs, students applied information from their previous coursework to accomplish their design. After the completion of the design, each student was asked to identify a topic to focus on independently. The students chose blast loading causing progressive collapse, and the students were able to deliver designs for buildings under blast loading successfully.

\section{Project Methodology}

\subsection{Class Layout}

Prestressing is defined as providing intended stresses to a structural element prior to loading and service in order to enhance the resistance of structural elements. For example, in concrete structures, concrete is known to have good resistance to compressive stresses; however, it is very weak under tensile stresses. Both stresses are presented in a girder under flexure. Prestressing for concrete structures provides pre-compression to regions under tensile stresses, hence the name "Prestressed Concrete". An example of prestressing was conducted for high school students at a university in the western United States in the summer of 2017 as part of summer trips. Rectangular plastic foam shapes and rubber bands were used to illustrate the concept. Two beams were used to explain the concept to students with no engineering background. The first beam was made of plastic foam only. The second beam was drilled end-to-end, and rubber bands were inserted from one end to the other. Then, the rubber bands were stretched, and knots were tied to prevent the sliding of rubber bands through the drilled hole inside the foam beam, as shown in Figure 2. Plastic foam in this illustration represents concrete, and rubber bands represent the prestressing steel (known as prestressing strands). Figure 2 shows the camber (upward deflection) generated in the prestressed plastic foam beam that offsets the 
deflection datum prior to service loadings from the horizontal line, as shown in a non-prestressed plastic foam beam to an upward parabolic datum, therefore, increasing the beam capacity.

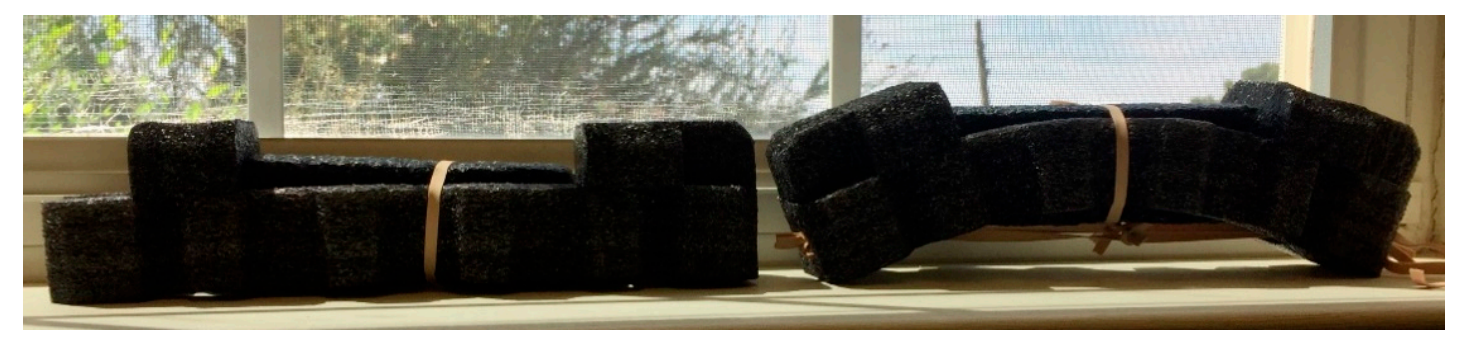

Figure 2. Prestressed plastic foam using rubber bands (on right) versus regular plastic foam beam (on left).

The CE 506-Prestressed Concrete class at a university in the western United States during the spring of 2017 was designed to provide the necessary concepts for prestressed concrete theory including historical background, prestressed materials, method of calculating concrete stresses, flexural capacity, shear capacity, indeterminate prestressed systems, deflection and crack control, and anchorage zone design. The class is a graduate course, with an enrollment of 12 master students during the spring of 2017. The class is proposed every two years during the spring semester to increase class enrollment.

For all topics mentioned above, three different design codes in the U.S. were discussed and examined, for the following building codes: "Precast-Prestressed Concrete Institute" [2], and "American Concrete Institute" [3], and for highway bridges "American Association of State Highway and Transportation Officials" [4].

Covering all fundamental topics required 12 weeks (including examinations) out of 16 weeks available in the spring semester. The last 4 weeks were utilized as a project month, where AASHTO-LRFD was explained in order to familiarize students with loads and analysis of bridges, tutorials were provided on two commercial software programs, and the students were guided throughout the entire project.

\subsection{Project Objectives and Description}

Aligning with [1], the class was designed to provide a practical project that involved the use of commercial software in structural engineering and a backcheck process used to check the results from automated modelling. The objectives of the practical project were to:

1. Educate students on commercial software widely used in designing prestressed girders in the state departments of transportation.

2. Educate student on bridge design manuals of the state departments of transportation to identify the difference between manuals and AASHTO LRFD 2014 [4].

3. Educate students on the backcheck process needed to identify mistakes in modelling, using commercial software to enhance the confidence in modelling results.

4. Prepare structural engineers of tomorrow in terms of practical knowledge, critical thinking, and engineering judgment.

The project was organized so that each student was asked to choose three U.S. states for superstructure design. The same bridge layout was used for all designs to allow the comparison of results between different states. The selection of students' states was based on the U.S. states where students were looking to work after graduation. A lottery draw was used to break the tie between students for repeatable selections. Figure 3 shows the student assignment (one state per student, 12 states in total). 


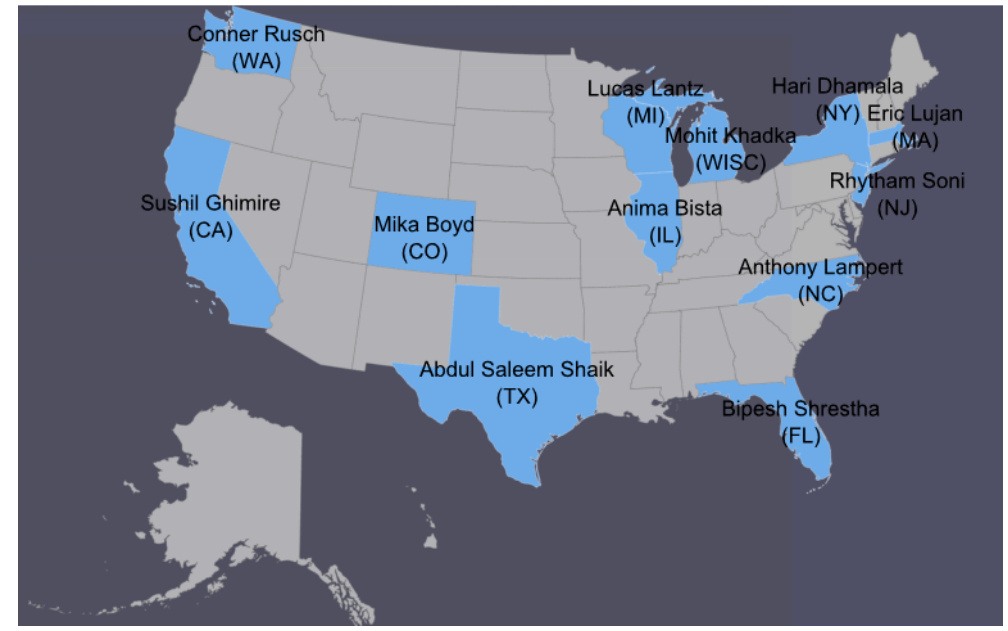

Figure 3. Students' selected states to conduct the class project.

The selection was representative to U.S. regions. The West region was represented by California, Washington, and Colorado, the Southwest region was represented by Texas, the Midwest region was represented by Michigan, Illinois, and Wisconsin, the Southeast region was represented by Florida and North Carolina, and the Northeast region was represented by New York, New Jersey, and Massachusetts. The advantage of having a state selection representative to the U.S. regions is that bridge practices are similar between states in the same region, therefore, the selection can be representative to all bridge practices in the U.S.

The project objective was to fully design the precast prestressed concrete girders (known as pretensioned girders) for a 2-span bridge of $25.09 \mathrm{~m}$ ( $85 \mathrm{ft}$.) each span and width of $11.9 \mathrm{~m}(39 \mathrm{ft}$.). Figure 4 shows the elevation for the proposed bridge; designing the reinforcement for the bridge slab was not required. The project was structured as follows:

1. Pre-design phase: literature review of the selected U.S. State's bridge manual during the semester to contrast the difference between state practice and AASHTO-LRFD 2014 [4], including all additional design requirements. The outcome of this literature review is highlighted in Section 4.1.

2. Design phase, which entailed sizing the pretensioned girders according to the standard sizes per each state bridge manual, calculating the amount of prestressed steel (known as the number of prestressing strands) to satisfy stresses, flexural, shear and deflection requirements, and providing structural drawings for the pretensioned girder and its reinforcement.

3. Post-design phase: head-to-head presentation by pairing students to contrast the differences in their design due to the use of two different states' design manuals. This presentation was used as the project final exam to evaluate the final design for each student.

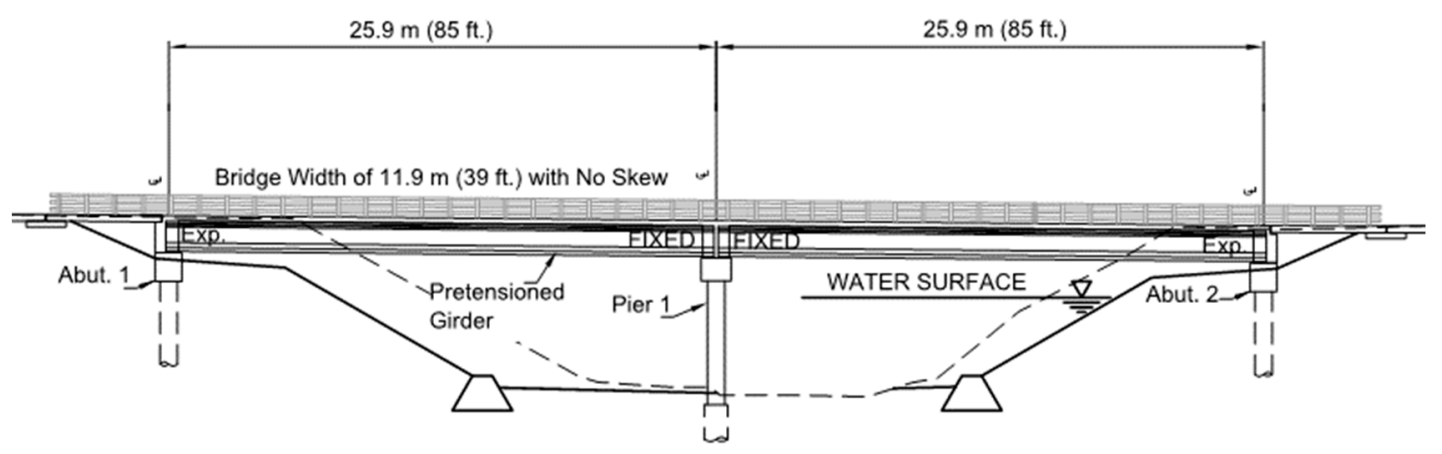

Figure 4. Bridge elevation. 
The design phase required students to conduct the analysis and design using two commercial software packages widely used in designing pretensioned girders: First, PGsSuper ${ }^{\mathrm{TM}}$ from Washington State Department of Transportation (WSDOT), which includes the design manual requirements for Washington State Department of Transportation (WSDOT), Texas Department of Transportation (TxDOT), and Kansas Department of Transportation (KDOT); Second, LEAP Bridge Concrete from Bentley Systems. The students were given the choice of using either PGSuper ${ }^{\mathrm{TM}}$ or LEAP Bridge Concrete, except for students assigned for the states of Washington and Texas.

The class instructor offered tutorials on using both software packages. In addition, Bentley Systems offered an online webinar for an hour for the students, along with a free student version of LEAP Bridge Concrete. The following paragraphs' sections provide an overview of both software packages.

PGSuper $^{\mathrm{TM}}$ is Precast-Prestressed Girder design, analysis, and load rating software. PGSuper ${ }^{\mathrm{TM}}$ can be used to design, check, and load rate precast-prestressed girder bridges in accordance with the AASHTO LRFD Bridge Design Specification and DOT agency-specific criteria. The flexural design feature computes the number and configuration of prestressing strands and the minimum required concrete release strength. The shear design feature determines the number, size, and spacing of transverse reinforcement for vertical shear, horizontal shear, bursting, and strand confinement. Specification checking evaluates girders for compliance with strength, service, and detailing criteria. Girders are evaluated for stresses and stability during handling and transportation. Temporary prestressing to control camber, improve stability, and reduce concrete release strengths may also be modelled. The capabilities and constraints of local fabricators have been accounted for in this software product. PGSuper ${ }^{\mathrm{TM}}$ has been designed to allow for future expansion and updating as design criteria and user expectations change. PGSuper supports 15 parametric beam shapes including I-beams, box beams, slab beams, T-beams, U-Beams, and decked beams. PGSuper's comprehensive roadway and bridge geometry capabilities enable accurate representation of bridge loadings and accurate detailing of bridge superstructures.

LEAP Bridge Concrete is used to improve decision making for design and construction while connecting and enhancing design workflow. It also allows the exchange of project information including bridge geometry, materials, loads, prestressing strand pattern, and shear reinforcement. Innovative analysis, design, and load-rating functionality come together in one advanced environment with LEAP Bridge Concrete. LEAP Bridge Concrete offers:

1. Computational bridge layout and design.

2. Analysis, design, and load rating for post-tensioned and reinforced concrete box girder, T-beam, and slab bridges.

3. Analysis, design, and load rating for simple and multi-span precast and prestressed concrete bridges.

4. Analysis and design of reinforced concrete abutments, piers, and foundations.

5. Analysis and design of spliced precast/prestressed bridge girders.

During the design phase, the students were asked to backcheck the design results of each software package used in their bridge superstructure design. The purpose of this phase is to verify the software design results and to detect any mistakes defined in the software during the pre-processing phase.

\section{Project Results}

\subsection{Literature Review on State Bridge Manuals}

During the pre-design phase, students were asked to prepare a literature review for their assigned states. Given the fact that each U.S. State DOT has its own interpretation of AASHTO-LRFD 2014 [4], students highlighted the differences and additional design requirements for their state bridge manual. Discussions were required throughout the project month to exchange knowledge between students and instructor. 
The benefits of the pre-design phase include:

1. Expanding the knowledge of different bridge design manuals (11 design manuals for each student) outside the assigned bridge design manual.

2. Helping students to identify the differences between AASHTO-LRFD 2014 [4] and state bridge design manuals for the later use of commercial software.

3. Knowledge exchange between students and instructor, where both sides learn from each other through discussions.

The following sections summarize the key student findings from state bridge manuals based on their assigned states.

\subsubsection{California}

California Department of Transportation (Caltrans) uses the state bridge design manual [10].

Based on the literature review that was conducted by Sushil Ghimire, key findings can be summarized as follows:

1. Among many standard girders, the I-girder is most commonly used and has been in use in California for nearly 60 years, with bridge span lengths normally ranging from $15.25 \mathrm{~m}$ to $38.1 \mathrm{~m}$ (50 ft. to $125 \mathrm{ft}$.). The bulb-tee girder is targeted for bridge spans up to from $24.4 \mathrm{~m}$ to $45.7 \mathrm{~m}$ (80 ft. to $150 \mathrm{ft}$.).

2. For economic reasons, prestressed concrete (PC) girders commonly use $15.24 \mathrm{~mm}(0.6 \mathrm{in}$.) diameter, $1860 \mathrm{MPa}(270 \mathrm{ksi})$, low relaxation strands. Using $12.7 \mathrm{~mm}(0.5 \mathrm{in}$.$) diameter strands is less$ common because the $15.24 \mathrm{~mm}$ ( $0.6 \mathrm{in}$.) diameter strands provide a significantly higher efficiency due to a $42 \%$ increase in capacity.

3. Live loads are based on the HL-93 design truck defined in AASHTO-LRFD 2014 [4] and permit truck P-13.

4. Zero-tension stress is permitted at service condition under dead load only.

\subsubsection{Colorado}

Colorado Department of Transportation (CDOT) uses the state bridge design manual [11].

Based on the literature review that was conducted by Mika Boyd, key findings can be summarized as follows:

1. Colorado use standard BT (Bulb T) girders.

2. The prestressing strand shall be $15.24 \mathrm{~mm}$ (0.6 in.) diameter, low-relaxation strand, with a design ultimate tensile strength of $1860 \mathrm{Mpa}(270 \mathrm{ksi})$.

3. Live loads are based on the HL-93 design truck defined in AASHTO-LRFD 2014 [4].

\subsubsection{Florida}

Florida Department of Transportation (FDOT) uses the state bridge design manual [12].

Based on the literature review that was conducted by Bipesh Shrestha, key findings can be summarized as follows:

1. The Florida-I Beams and the AASHTO Type II Beam are the Department's standard prestressed concrete I-shaped beams and are used in the design of all new bridges and bridge widenings, with I-shaped beams as applicable.

2. All pretensioning strands shall follow ASTM A416, $1860 \mathrm{MPa}(270 \mathrm{ksi})$, low-relaxation, prestressing strands for the design of prestressed beams. The use of stress-relieved strands is prohibited. The use of straight-strand configurations is preferred over draped strand configurations.

3. Live loads are based on the HL-93 design truck defined in AASHTO-LRFD 2014 [4]. 


\subsubsection{Illinois}

Illinois Department of Transportation (IDOT) uses the state bridge design manual [13].

Based on the literature review that was conducted by Anima Bista, key findings can be summarized as follows:

1. High-Performance Concrete shall be the standard concrete for prestressed bridge elements. The minimum concrete strength $\left(\mathrm{f}^{\prime} \mathrm{c}\right)$ for prestressed concrete bridge beams shall be $48.25 \mathrm{MPa}(7 \mathrm{ksi})$. The concrete strength at transfer $\left(\mathrm{f}^{\prime} \mathrm{ci}\right) \mathrm{can}$ be taken as $0.6 \mathrm{f}^{\prime} \mathrm{c}$ unless the designer determines a higher transfer strength is necessary.

2. Prestressing steel for all new prestressed-precast girder construction shall be uncoated 7-wire, low-relaxation (low-lax) strands with a nominal diameter of $12.7 \mathrm{~mm}(0.5 \mathrm{in}$.) and ultimate strength of $1860 \mathrm{MPa}(270 \mathrm{ksi})$. Strands with a nominal diameter of $15.24 \mathrm{~mm}(0.6 \mathrm{in}$.$) . are not$ permitted. Stress-relieved strands are not permitted for the new construction of precast pestressed concrete (PPC) girders.

3. For New or Replacement Projects on mainline and ramp flyover bridges and bridge culverts only, the design truck in the AASHTO LRFD 2014 [4] Article 3.6.1.2.2 shall be replaced with the IL-120 at 1.25 times the HL-93 design truck defined in AASHTO-LRFD 2014 [4].

\subsubsection{Texas}

Texas Department of Transportation (TxDOT) uses the state bridge design manual [14].

Based on the literature review that was conducted by Abdulu Saleem Shaik, key findings can be summarized as follows:

1. Texas uses pretensioned concrete I-girders, U-beams, slab beams, spread slab beams, decked slab Beams, double-tee beams, box beams, spread box beams (X-beams), straight plate girders, and curved plate girders.

2. Live loads are based on the HL-93 design truck defined in AASHTO-LRFD 2014 [4].

\subsubsection{Massachusetts}

Massachusetts Department of Transportation (MassDOT) uses the state bridge design manual [15]. Based on the literature review that was conducted by Eric Lujan, key findings can be summarized as follows:

1. Massachusetts, along with five other New England states, Connecticut, Maine, New Hampshire, Rhode Island, and Vermont, joined together to design the New England Bulb Tee girder (NEBT). The former New England standard was the AASHTO I-girder, but this particular girder began to suffer limitations in its range of applicability in New England. The New England bulb tee was designed with the federal metrication in mind and developed on hard metric units.

2. All pretensioning strands shall be $15.24 \mathrm{~mm}(0.6 \mathrm{in}$.), uncoated 7-wire, low relaxation steel strands and shall conform to AASHTO M 203. The nominal tensile strength of the pretensioning strands shall be $1860 \mathrm{MPa}(270 \mathrm{ksi})$. The minimum 28-day compressive strength shall be $45 \mathrm{Mpa}$ ( $6.5 \mathrm{ksi})$.

3. Live loads are based on the HL-93 design truck defined in AASHTO-LRFD 2014 [4].

\subsubsection{Michigan}

Michigan Department of Transportation (MDOT) uses the state bridge design manual [16].

Based on the literature review that was conducted by Lucas Lantz, key findings can be summarized as follows:

1. MDOT uses AASHTO Types 1-4, with concrete strengths of $34.5 \mathrm{MPa}-55 \mathrm{~m} \mathrm{MPa} \mathrm{(5} \mathrm{ksi-8} \mathrm{ksi)}$ concrete allowed if the span is less than or equal to $34.75 \mathrm{~m}$ (114 ft.), in the Upper Peninsula, Wisconsin type I beams ( $1780 \mathrm{~mm}$ or $70 \mathrm{in}$. deep) can be used for spans up to $36.6 \mathrm{~m}$ (120 ft.) with 
a concrete strength of $34.5 \mathrm{MPa}-55 \mathrm{~m} \mathrm{MPa} \mathrm{(5} \mathrm{ksi-8} \mathrm{ksi),} \mathrm{and} \mathrm{in} \mathrm{the} \mathrm{Lower} \mathrm{Peninsula,} \mathrm{Michigan}$ 1800 Girder (1800 mm or 70.9 in. deep) at strengths of $34.5 \mathrm{MPa}-55 \mathrm{~m} \mathrm{MPa} \mathrm{(5} \mathrm{ksi-8} \mathrm{ksi)} \mathrm{concrete}$ can be used for spans up to $44.2 \mathrm{~m}$ (145 ft.).

2. Live loads are based on $125 \%$ of the HL93 design truck defined in AASHTO-LRFD 2014 [4].

\subsubsection{North Carolina}

North Carolina Department of Transportation (NCDOT) uses the state bridge design manual [17]. Based on the literature review that was conducted by Anthony Lampert, key findings can be summarized as follows:

1. Girders can be AASHTO Type II, Type IV, Type V, Type VI, 63 in. or 72 in. Modified Bulb Tee.

2. The two acceptable strand diameters are $12.7 \mathrm{~mm}(0.5 \mathrm{in}$.) and $15.24 \mathrm{~mm}(0.6 \mathrm{in}$.$) , both at 1860 \mathrm{MPa}$ (270 ksi). When using draped strands, if a straight strand design can be used by adding up to six straight strands, then detail using the straight strands. If it takes more than six straight strands, then keep the draped design. The slope of draped strands shall not exceed $12.5 \%$.

3. Live loads are based on the HL-93 design truck defined in AASHTO-LRFD 2014 [4].

\subsubsection{New Jersey}

New Jersey Department of Transportation (NJDOT) uses the state bridge design manual [18].

Based on the literature review that was conducted by Rhytham Soni, key findings can be summarized as follows:

1. Uncoated 7-wire prestressing steel low relaxation strands, conforming to ASTM A416 (AAHSTO M 203), $1860 \mathrm{MPa}(270 \mathrm{ksi})$, shall be used.

2. Live loads are based on the HL-93 design truck defined in AASHTO-LRFD 2014 [4].

\subsubsection{New York}

New York Department of Transportation (NYDOT) uses the state bridge design manual (Bridge Design Specification [19].

Based on the literature review that was conducted by Hari Dhamala, key findings can be summarized as follows:

1. The preferred I-Girder shape is the Bulb-Tee. High-Performance Concrete shall be the standard concrete for prestressed bridge elements. The minimum concrete strength $\left(f^{\prime} \mathrm{c}\right)$ for prestressed concrete bridge beams shall be $69 \mathrm{MPa}(10 \mathrm{ksi})$. The concrete strength at transfer $\left(\mathrm{f}^{\prime} \mathrm{ci}\right)$ can be taken as $0.7 \mathrm{f}^{\prime} \mathrm{c}$, unless the designer determines a higher transfer strength is necessary.

2. Only $1860 \mathrm{MPa}(270 \mathrm{ksi})$, Low-Relaxation Prestressing Steel Strand shall be used. The standard diameter used by NYSDOT is $15.24 \mathrm{~mm}$ (0.6 in.).

3. Live loads are based on the HL-93 defined design truck in AASHTO-LRFD 2014 [4].

\subsubsection{Washington}

Washington Department of Transportation (WSDOT) uses the state bridge design manual (Bridge Design Specification [20].

Based on the literature review that was conducted by Conner Rusch, key findings can be summarized as follows:

1. WSDOT differs from AASHTO girders as it uses all of its own type of girders. Every girder has similar cross sections but varies based on the depth needed. The girders start at $1067 \mathrm{~mm}$ (42 in.) depth and go all the way to $2540 \mathrm{~mm}$ (100 in.) depth.

2. The typical strand is AASHTO M 203 of $1860 \mathrm{MPa}(270 \mathrm{ksi})$, low relaxation or stress-relieved. Reinforcing bars are AASHTO M 275 Type II. The parallel wires are AASHTO M 204 Type WA. 
3. The design truck used by WSDOT is a HL-93 defined design, which means the use of the design truck HS-20 and the use of a design lane load. This is the same as AASHTO.

4. A very conservative assumption of zero-tension under service load along with the requirement of lifting and hauling analyses.

\subsubsection{Wisconsin}

Wisconsin Department of Transportation (WisDOT) uses the state bridge design manual (Bridge Design Specification [21].

Based on the literature review that was conducted by Mohit Khadka, key findings can be summarized as follows:

1. WisDOT employs two prestressed I-girder section families. One I section family follows the AASHTO standard section, while the other section family follows a wide flange bulb-tee.

2. Low relaxation strand diameters currently used in prestressed I-girders are $12.7 \mathrm{~mm}(0.5 \mathrm{in}$.) and $15.24 \mathrm{~mm}(0.6 \mathrm{in}$.).

3. Live loads are based on the HL-93 defined design truck in AASHTO-LRFD 2014 [4].

\subsection{Project Outcome}

Students (except for students assigned to design the bridges in Texas and Washington) were free to choose the software to perform the analysis and design of the bridge girders. Students assigned to design in Texas and Washington were asked to perform the design in PGSuper, as this program is considered to be the state-certified software. By the end of student selection, three bridges were modelled and designed using PGSuper (Texas, Michigan, and Washington); the other bridges (nine bridges) were designed using LEAP Bridge Concrete.

Table 1 shows a summary of the project findings. Four states allowed the use of standard AASHTO prestressed girders; two states (New Jersey and Massachusetts) used New England Bulb T; other states used their own specified girders. All bridges, except for bridges designed in California and Michigan, required five girders of $2.42 \mathrm{~m}(8 \mathrm{ft}$.) spacing. However, in California and Michigan, six girders were used at a spacing of $1.95 \mathrm{~m}(6.4 \mathrm{ft}$.) due to the requirements of their state bridge design manuals. Ten students used $15.24 \mathrm{~mm}$ (0.6 in.) strand diameter for prestressing strands. However, two students chose to use $12.7 \mathrm{~mm}(0.5 \mathrm{in}$.) diameter strands, as shown in Table 1 . Table 1 also shows the number of prestressing strands required for each state using straight and either harped or debonded strands or a combination of both.

Table 1. Project major findings.

\begin{tabular}{|c|c|c|c|c|c|c|c|}
\hline State & Software & Girder Type & $\begin{array}{l}\text { No. of } \\
\text { Girders }\end{array}$ & Strand Diameter & $\begin{array}{l}\text { No. of } \\
\text { Straight } \\
\text { Strands }\end{array}$ & $\begin{array}{l}\text { No. of } \\
\text { Harped } \\
\text { Strands }\end{array}$ & $\begin{array}{c}\text { No. of } \\
\text { Debonded } \\
\text { Strands }\end{array}$ \\
\hline California & LEAP & CA I42 & 6 & $15.24 \mathrm{~mm}(0.6 \mathrm{in})$ & 14 & 4 & - \\
\hline Colorado & LEAP & BT-54 & 5 & $15.24 \mathrm{~mm}(0.6 \mathrm{in})$ & 16 & 4 & - \\
\hline Florida & LEAP & FIB54 & 5 & $12.70 \mathrm{~mm}(0.5 \mathrm{in})$ & 25 & - & 5 \\
\hline Illinois & LEAP & AASHTO III & 5 & $15.24 \mathrm{~mm}(0.6 \mathrm{in})$ & 20 & 4 & 2 \\
\hline Texas & PGSuper & TX 46 & 5 & $15.24 \mathrm{~mm}(0.6 \mathrm{in})$ & 24 & - & - \\
\hline Massachusetts & LEAP & NEBT 1200 & 5 & $15.24 \mathrm{~mm}(0.6 \mathrm{in})$ & 16 & 4 & - \\
\hline Michigan & PGSuper & AASHTO IV & 6 & $15.24 \mathrm{~mm}(0.6 \mathrm{in})$ & 16 & 2 & - \\
\hline North Carolina & LEAP & AASHTO IV & 5 & $15.24 \mathrm{~mm}(0.6 \mathrm{in})$ & 14 & 4 & - \\
\hline New Jersey & LEAP & NEBT 1400 & 5 & $12.70 \mathrm{~mm}(0.5 \mathrm{in})$ & 28 & 4 & - \\
\hline New York & LEAP & AASHTO III & 5 & $15.24 \mathrm{~mm}(0.6 \mathrm{in})$ & 18 & 4 & - \\
\hline Washington & PGSuper & W58G & 5 & $15.24 \mathrm{~mm}(0.6 \mathrm{in})$ & 14 & 4 & - \\
\hline Wisconsin & LEAP & Wisc $45 \mathrm{~W}$ & 5 & $15.24 \mathrm{~mm}(0.6 \mathrm{in})$ & 22 & - & 4 \\
\hline
\end{tabular}

After the completion of the design of bridge girders using commercial software, the students successfully performed calculations using spreadsheets (Mathcad or Excel) to backcheck and verify the 
design input/output. The average of the difference between software results and manual results was within $5 \%$.

\section{Project Assessment}

Quantitative and qualitative evaluation methods were used to evaluate each student as follows:

1. Students were asked to submit a full design booklet along with design drawings. The documents were then evaluated by the instructor.

2. Performance of each student was evaluated throughout the entire project month including quality of work and student Q\&A sessions during office hours.

3. Head-to-head presentations at the end of the project were performed, where pairs of students were assigned to present at the same time to contrast the differences in their designs.

The instructor used the assessment measurements listed above to evaluate the performance of each student. The project objectives were achieved for each student. The students successfully learned and became good users of one or two commercial software packages. In addition, students were able to emphasize the difference between their bridge design manuals and AASHTO-LRFD 2014 [4] (as discussed in Section 4.1) and to update the software design requirements to match their state design manuals. Each student was able to verify the design obtained from commercial software using hand calculations or spreadsheets.

\section{Student Feedback}

Students were asked to provide project feedback anonymously, one year after the completion of the class. The purpose of the postponed feedback is to ensure that most of the students had graduated and joined the workforce and to measure the project impact on their professional careers.

The questionnaire was sent to all the class members (12 students); however, the response rate was $92 \%$ (11 students).

The requested feedback was divided into three questions with satisfaction points scaled from 0 (Very unsatisfied) to 10 (Very satisfied) and the other three questions where students were asked to write down brief answers. Figure 5 shows bar charts for anonymous responses to the following.

1. Rate the overall project experience.

2. Rate the overall experience with commercial software.

3. Rate the overall experience with the state bridge manual.

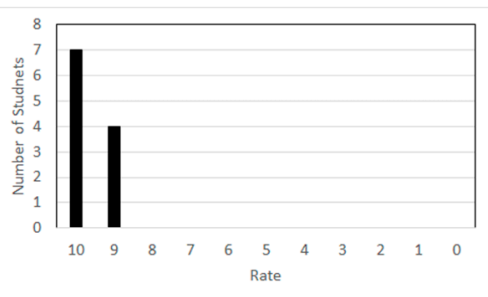

(a)

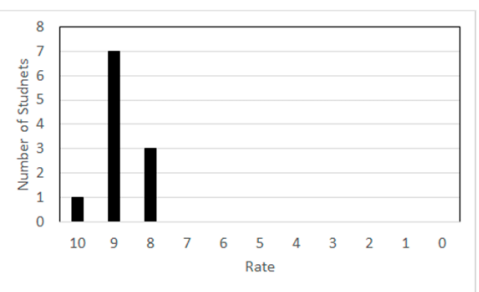

(b)

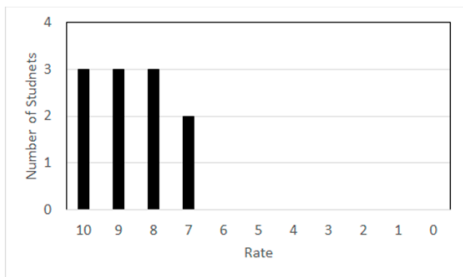

(c)

Figure 5. Student ratings for the questionnaire: (a) project experience, (b) experience with commercial software, and (c) experience with the state bridge manual.

Seven students rated 10 for the overall project experience, versus four students who rated it as a 9 . For the experience with commercial software, one student rated it as a 10, seven students as a 9, and three students with a rating of 8 . Some students reported that they had technical problems with the software crashing. For the experience with different state design manuals, groups of three students 
each rated it as a 10,9 , and 8 , and the remaining students rated it as a 7 . Some students reported that the manuals were not updated in recent years (some manuals still had versions from 2008 or earlier).

The questions asking for brief written answers were as follows:

4. What are the project features that contributed the most to your learning and practical experience?

5. If you graduate, does this project foster your job search or your performance if you get a structural engineering position?

6. What did you think of the backcheck process used to check your model and the use of commercial software?

Table 2 summarizes the students' answers to questions 4, 5 and 6 in a similar answer format. Most of the students reported that learning new commercial software was a rewarding experience, followed by the backcheck process and the familiarity with bridge design manuals. For the job search question, most students stated that the project, including experience with commercial software, bridge design manuals, and the backcheck process, enriched their resume. Two students even stated that they got the chance to implement what they had learned in the real professional world. For the evaluation of the backcheck process, students agreed that the process is necessary for any program in order to gain confidence in the design output. Tables A1-A3 in Appendix A state the detailed unprocessed students' answers. Opinions in Table 2 match what is stated in Tables A1-A3.

Table 2. Summary of student feedback from Questions 4, 5, and 6.

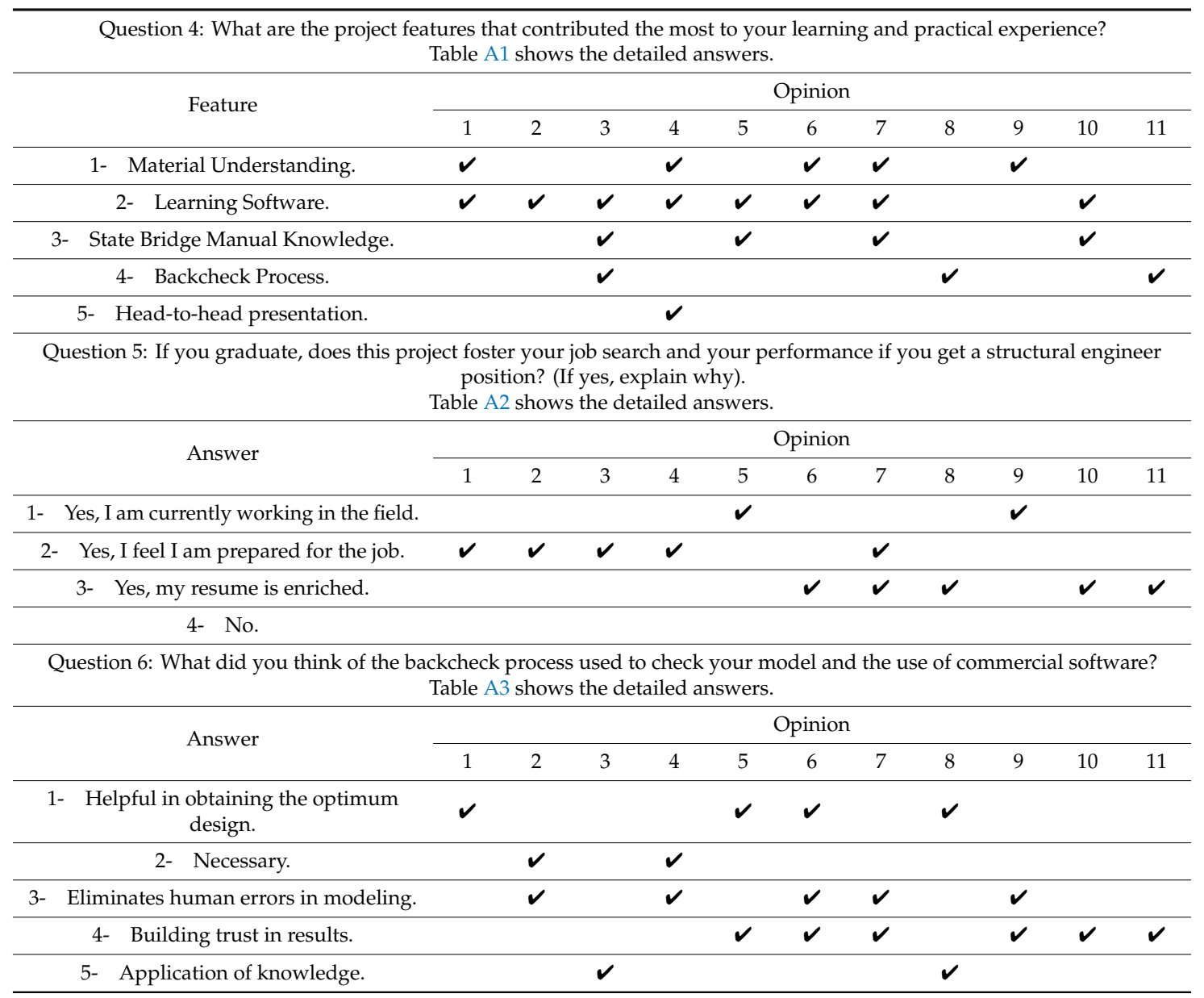

\section{Discussion and Conclusions}

During the spring of 2017 at a university in the western United States, an attempt was taken to design a class to serve a project-based course. CE 506 "Prestressed Concrete" was designed to provide 
the essential knowledge of prestressed concrete theory and to facilitate the use of commercial software through the design project of prestressed concrete girders for bridge superstructures.

The project-based class aligned with "A Vision for the Future of Structural Engineering and Structural Engineers: A Case for change", which is published by the Structural Engineering Institute (SEI 2013 [1]). The case for change aims to develop the educational approaches to tackle challenges in structural engineering such as automation in design and analysis.

Twelve students were assigned to design the same bridge superstructure girders but in different U.S. states. The differences in designing such a project in different states included the differences in design requirements in state bridge manuals, differences in state standard prestressed girders, and differences in state permit trucks. Furthermore, the project helped students in gaining practical experience in commercial software packages, interpreting state manuals, and preparing the design submittal in the U.S. state in which they were looking to work post-graduation.

The project was structured into three phases: first, the pre-design phase, where students were asked to prepare a literature review on the differences between the assigned state's bridge design manual and AASHTO-LRFD 2014 [5]. Second, the design phase, where students were asked to use one of two commercial software packages to design the bridge superstructure's girders and backcheck the design using hand calculations or spreadsheets. Third, the post-design phase, where students were asked to submit design booklets with drawings, along with a head-to-head presentation where pairs of students contrasted the differences in their designs.

Several conclusions and outcomes can be drawn from the class project:

- All students were able to complete all of the project requirements, including a literature review of the assigned bridge manual, modelling, and analysis of the bridge superstructure's girders using one software package, backchecking the design of prestressed girders using hand calculations or spreadsheets, and performing a head-to-head presentation for their projects.

- Students' feedback showed that conducting a literature review on the state bridge design manual was necessary to point out the differences between the state bridge design manual and AASHTO-LRFD 2014 [4].

- Students' feedback showed that learning to use commercial software was a rewarding experience which helped them to apply the gained knowledge in a practical project.

- Students' feedback showed that the backchecking process helped them to identify mistakes in inputs and to verify the output design results. Students agreed that the backchecking process was necessary to build confidence in their design.

- Collaboration between instructors at the university level with the leaders and developers of commercial software was necessary to accomplish a good educational environment. Commercial software leaders and developers provided great assistance throughout the project through webinars and free student versions of software packages.

- Due to the time limitation and restriction, only one month was devoted during the class to the project. It will be useful for instructors to develop a stand-alone class based on this class experience; for example, a class on prestressed concrete theory should be a prerequisite class for prestressed concrete projects and applications.

- Similar project-based classes can be developed for many courses in structural engineering, such as steel structures, concrete structures, and highway bridges.

- Several topics can be used as bases for a project-based class on prestressed concrete, such as post-tensioned slabs for buildings, prestressed beams in garages, concrete box girders in bridges, and prestressed tanks.

Author Contributions: Conceptualization, Islam M. Mantawy; Formal analysis, Conner Rusch, Sushil Ghimire, Lucas Lantz, Hari Dhamala, Bipesh Shrestha, Anthony Lampert, Mohit Khadka, Anima Bista, Rhytham Soni, Abdulu Saleem Shaik, Eric Lujan and Mika Boyd; Methodology, Islam M. Mantawy; Resources, Islam M. Mantawy, Sushil Ghimire, Lucas Lantz, Hari Dhamala, Bipesh Shrestha, Anthony Lampert, Mohit Khadka, Anima Bista, 
Rhytham Soni, Abdulu Saleem Shaik, Eric Lujan, Mika Boyd, Richard Pickings and Alexander Mabrich; Software, Islam M. Mantawy, Conner Rusch, Sushil Ghimire, Lucas Lantz, Hari Dhamala, Bipesh Shrestha, Anthony Lampert, Mohit Khadka, Anima Bista, Rhytham Soni, Abdulu Saleem Shaik, Eric Lujan, Mika Boyd, Richard Pickings and Alexander Mabrich; Supervision, Islam M. Mantawy; Writing—original draft, Islam M. Mantawy; Writing—review \& editing, Islam M. Mantawy, Richard Pickings and Alexander Mabrich.

Funding: No funding was associated with the development of this article.

Acknowledgments: The instructor appreciated all the help provided by BridgeSight Inc. through the free online version of PGSuper ${ }^{\mathrm{TM}}$. The instructor appreciated the help provided by Bentley Systems by providing a free student version of LEAP Bridge Concrete for each student along with offering a free webinar. The authors believe that collaboration with commercial software owners and developers enhanced the educational endeavors.

Conflicts of Interest: The authors declare no conflict of interest.

\section{Appendix A}

Table A1. Students' answers for Evaluation Question 4: What are the project features that contributed the most to your learning and practical experience?

\begin{tabular}{|c|c|}
\hline Opinion & Answer \\
\hline 1 & $\begin{array}{l}\text { Fully understanding the material presented during class and applying it on a project that mimics a problem that } \\
\text { could be encountered as an engineer is invaluable. It is also important to see each equations significance and how it } \\
\text { applies practically. }\end{array}$ \\
\hline 2 & Using the software was interesting and challenging as well \\
\hline $\begin{array}{l}\mathrm{I} \\
\mathrm{t} \\
\mathrm{t} \\
\mathrm{c} \\
\mathrm{t}\end{array}$ & $\begin{array}{l}\text { I would say the combination of the different bridge manual, the software, and having to do the hand calculations } \\
\text { together contributed. The manual forced us to directly derive information from a code similar yet different from } \\
\text { the standard AASHTO code that comes across many classes. Being able to differentiate between is likely a valuable } \\
\text { skill since even just updates of identical codes have differences. The differences are often subtle and hard to point, } \\
\text { so in this regard, the project had some practical application outside of just bridge design. The software and hand } \\
\text { calculations in conjunction work together in a way to help improve the student's knowledge of pre-stressed bridge } \\
\text { design by allowing the user to quickly design an actual bridge but at the same time make them look at the details } \\
\text { behind the design. It also gives an appreciation for the number of iterations done and how it would be impossible } \\
\text { to optimize bridges in the same fashion without software. }\end{array}$ \\
\hline 4 & $\begin{array}{l}\text { This project was the direct application of study materials we covered in the class, in the practical field. Since each of } \\
\text { us were assigned different state, we got a chance to learn about several states by consulting with each other. The } \\
\text { head on presentation was also a good part of this project. }\end{array}$ \\
\hline 5 & $\begin{array}{l}\text { The research into the state manual helped realize the work that would go into finding the design criteria for bridge } \\
\text { design. The software showed how much quicker designs can be completed then by hand. }\end{array}$ \\
\hline 6 & Exposure to practical software use and industrial knowledge. \\
\hline i & $\begin{array}{l}\text { The project we did was based on the bridge practice that would be possible in the real world. We used all our } \\
\text { knowledge of the course we took on Prestressed Concrete and Reinforced Concrete while working on the project. It } \\
\text { helped us to get familiar with the real-world practice where the commercial software is used to design the } \\
\text { engineering structures. Learning the software was helpful to get started with the first taste of how the industries } \\
\text { work and what is going on in the engineering world of design. It gave a feeling that I was in the industry and } \\
\text { involved in some serious design that is about to get out into the world from my desktop. }\end{array}$ \\
\hline 8 & $\begin{array}{l}\text { Backchecking the software calculations by hand contributed most as it helped me to deeply understand the } \\
\text { concepts and equations involved. }\end{array}$ \\
\hline $\begin{array}{l}\mathrm{T} \\
\mathrm{V} \\
\mathrm{r} \\
\mathrm{c} \\
\mathrm{r}\end{array}$ & $\begin{array}{l}\text { The state bridge manuals are for the specific state, while the AASHTO manual is a general manual for all the states. } \\
\text { While comparing the state of New Jersey and knowing about the differences of the state manuals with the AASHTO } \\
\text { manual, it helped me understand the reasons why AASHTO has certain specifications while a few states have a few } \\
\text { amendments to it based on the condition of the state like the weather, the material availability and other various } \\
\text { reasons. This helped me in understanding how the manual is produced instead of following the manual as it is. }\end{array}$ \\
\hline 10 & $\begin{array}{l}\text { Learning commercial software along with the state bridge manual comparing with the AASTHO code which we } \\
\text { basically followed in class was the most exciting part of this project. }\end{array}$ \\
\hline 11 & Verifying the formulas with the software. \\
\hline
\end{tabular}


Table A2. Students' answers for Evaluation Question 5: If you graduate, does this project foster your job search and your performance if you get a structural engineer position? (If yes, explain why).

\begin{tabular}{|c|c|}
\hline Opinion & Answer \\
\hline 1 & $\begin{array}{l}\text { Yes, a project like this widens the scope of jobs I would feel comfortable applying for because it closely mimics } \\
\text { what would be expected for an engineer dealing with pre-stressed concrete design. Understanding different types } \\
\text { of software also gives you an advantage when looking for and applying for jobs. }\end{array}$ \\
\hline 2 & $\begin{array}{l}\text { I hope so. I believe most of the companies use commercial software in their design, so having experience already } \\
\text { with at least one of the software might give you an edge. }\end{array}$ \\
\hline $\begin{array}{l}\text { I } \\
\text { r } \\
r \\
r \\
t \\
c \\
c \\
\text { h } \\
c\end{array}$ & $\begin{array}{l}\text { It probably would help most in an instant where I was trying to be a bridge designer, as pre-stressed steel isn't as } \\
\text { widespread in other applications, although having some background knowledge I'm sure can prove useful in the } \\
\text { right instant. Likewise, it's another design project where reading codes with a unique set of design issues, which in } \\
\text { reality is good practice for any aspiring engineer because the goal of a degree in engineering is not to make us able } \\
\text { to know how to design everything, but how to approach design. The project is also an instance where the students } \\
\text { directly were involved with commercial software, which usually in the workplace regardless of what's being } \\
\text { designed there will be some use of computer design programs. For instance, I've never used Pgsuper at work, but } \\
\text { have come across other commercial software like Enercalc or Hilti, and learning how to utilize these tools and } \\
\text { demonstrating that you can learn them can be valuable when trying to achieve employment. }\end{array}$ \\
\hline 4 & $\begin{array}{l}\text { Sure. This project has increased my knowledge in the field of prestressed concrete. This is the first course in } \\
\text { Prestressed concrete for me. Since the project work was the exact application of studied materials in class with the } \\
\text { use of commercial software, this will definitely be a good point in my resume to attract employer's attention. }\end{array}$ \\
\hline 5 & $\begin{array}{l}\text { Yes, I am currently working a designing a simple span prestressed concrete bridge in southern Colorado. I am } \\
\text { following the steps in class we took for the final project as I work through it. I am using PGSuperTM for analysis. }\end{array}$ \\
\hline 6 & $\begin{array}{l}\text { Yes. Because this allows me to add more software to my skills. If I plan to go towards the path of a bridge engineer, } \\
\text { it will add as a strong attribute to my profile because I can show the experience of girder design and ability to use } \\
\text { the two software. }\end{array}$ \\
\hline 7 & $\begin{array}{l}\text { This project is a lot of help for the job search as I can now add an extra point in my resume for my skills with the } \\
\text { software I used and the course I took to undergo this project. I already feel that I am the beginner practitioner of the } \\
\text { software even though I had a short time to learn and get started with the software. }\end{array}$ \\
\hline 8 & $\begin{array}{l}\text { Yes, this will help me in a job search as I can put that I have some industrial design experience through a course } \\
\text { project in my resume. }\end{array}$ \\
\hline 9 & $\begin{array}{l}\text { Yes, I plan to work in a bridge design company after I graduate, for which taking the Prestressed Concrete course } \\
\text { was helpful as it made me understand the design of prestressed structures along with the commercial software and } \\
\text { state manuals. }\end{array}$ \\
\hline 10 & $\begin{array}{l}\text { I am working mostly on steel design on my job after graduation. However, it might have helped very well on my } \\
\text { experience as I did put in my resume. }\end{array}$ \\
\hline 11 & $\begin{array}{l}\text { I am sure this project experience would be of very helpful for a Structural Engineer position, right now I am } \\
\text { working in Construction Management. }\end{array}$ \\
\hline
\end{tabular}

Table A3. Students' answers for Evaluation Question 6: What did you think of the backcheck process used to check your model and the use of commercial software?

\begin{tabular}{c} 
Opinion \\
$\begin{array}{l}\text { It was good to be able to backcheck your calculations with the software as well as backcheck the software with your } \\
\text { calculations. It is fast and efficient to be able to start with a base design and make numerous changes within the } \\
\text { software program to extract answers fast, which are then backchecked with hand calculations. }\end{array}$ \\
\hline $2 \quad \begin{array}{l}\text { I think it is absolutely necessary because as it is said for a software "garbage in garbage out". You need to be sure } \\
\text { what your getting is not garbage. }\end{array}$ \\
$\begin{array}{l}\text { Considering I should probably backcheck the majority of work I do with any software baring extensive use with it, } \\
\text { it's good practice to backcheck or at least do simple calculations that are going to give one a general idea about the } \\
\text { computer results. It also proves that we have the knowledge to properly operate the software because we know, for } \\
\text { the most part, what is going on behind the 50-page result list and the fancy 3D model. }\end{array}$ \\
$\begin{array}{l}\text { The backcheck process is an essential part of the project. There may be some mistakes while inputting data in the } \\
\text { software which we won't be able to figure out unless it is checked with some hand calculations. }\end{array}$ \\
\hline $\begin{array}{l}\text { The backcheck was useful to show that calculations are the same as the program. } \\
\text { The backcheck was useful because it allowed us to check the errors and where the errors were. This way we could } \\
\text { go back into the software and correct the errors. }\end{array}$ \\
\hline
\end{tabular}


Table A3. Cont.

\begin{tabular}{ll}
\hline Opinion & \multicolumn{1}{c}{ Answer } \\
\hline 7 & $\begin{array}{l}\text { The software is designed by human and it is there to help our jobs get done easily. However, it is always a good } \\
\text { idea to at least check once with the skills you have in hand to see that the code is working right and there is no bug. } \\
\text { We can always backcheck our designs and match our hand calculations with the results from the software to see if } \\
\text { we are in the same boat. In my understanding, the backcheck increases our understanding of the process and helps } \\
\text { us get more accurate results. }\end{array}$ \\
\hline $8 \quad \begin{array}{l}\text { The backcheck process was very helpful for me to really understand every part of why the code has certain } \\
\text { requirements for pre-stressed girders. }\end{array}$ \\
$\begin{array}{l}\text { The backcheck process is always important in structural design as the software used to design cannot be always } \\
\text { trusted. With the possibility of human error in input to the software or the software coded to design in a certain } \\
\text { way can be different from what actually the designer wanted it to be designed. Hence the backcheck process } \\
\text { verifies the output of the software, thus confirming the appropriate use of the designed obtained through it. }\end{array}$ \\
$10 \quad \begin{array}{l}\text { It is always a nice idea to compare the results from the software with our course learnings and hand calculations. } \\
\text { Most of all results were matching between the software and my hand calculation which made me feel confident to } \\
\text { use the commercial software if I will be involved in the prestressed concrete domain in my job in the future. }\end{array}$ \\
\hline $11 \quad$\begin{tabular}{l} 
It builds my confidence to use the software and exposure to use the software in the future at the professional level. \\
\hline
\end{tabular}
\end{tabular}

\section{References}

1. SEI. A Vision for the Future of Structural Engineering and Structural Engineers: A Case for Change; A Board of Governors Task Committee Paper; Structural Engineering Institute (SEI): Reston, VA, USA, 16 October 2013.

2. PCI Design Handbook, 8th ed.; Precast and Prestressed Concrete Institute: Chicago, IL, USA, 2017.

3. American Concrete Institute ACI Committee 318. Building Code Requirements for Structural Concrete ACI318-17 and Commentary (ACI 318R-17); American Concrete Institute: Farmington Hills, MI, USA, 2017.

4. AASHTO LRFD. Bridge Design Specifications, 7th ed.; American Association of State Highway and Transportation Officials: Washington, DC, USA, 2014.

5. Federal Highway Administration (FHWA). National Bridge Inventory; U.S. Federal Highway Administration: Washington, DC, USA, 2013.

6. Quinn, K.A.; Albano, L.D. Problem-based learning in structural engineering education. J. Prof. Issue Eng. Educ. Pract. 2008, 134, 329-334. [CrossRef]

7. Johnson, P.A. Problem-based, cooperative learning in the engineering classroom. J. Prof. Issue Eng. Educ. Pract. 1999, 125, 8-11. [CrossRef]

8. Worcester Polytechnic Institute (WPI). Undergraduate Catalog; WPI: Worcester, MA, USA, 2006; Available online: http://www.wpi.edu (accessed on 25 May 2019).

9. Chinowsky, P.S.; Brown, H.; Szajnman, A.; Realph, A. Developing knowledge landscapes through project-based learning. J. Prof. Issue Eng. Educ. Pract. 2006, 132, 118-124. [CrossRef]

10. Bridge Design Specifications; California Department of Transportation, Office of Structural Design: Sacramento, CA, USA, 2008.

11. Bridge Design Manual; Colorado Department of Transportation: Denver, CO, USA, 2018.

12. Structures Manual; Florida Department of Transportation: Tallahassee, FL, USA, 2018.

13. Bridge Manual; Illinois Department of Transportation, Bureau of Bridge and Structures: Springfield, IL, USA, 2012.

14. Bridge Design Manual_LRFD; Texas Department of Transportation: Austin, TX, USA, 2015.

15. LRFD Bridge Manual; Massachusetts Department of Transportation: Boston, MA, USA, 2013.

16. Bridge Design Manual; Michigan Department of Transportation: Lansing, MI, USA, 2018.

17. Structures Design Manual; North Carolina Department of Transportation: Raleigh, NC, USA, 2007.

18. Bridges and Structures Design Manual, 6th ed.; State of New Jersey Department of Transportation: Ewing Township, NJ, USA, 2016.

19. Bridge Manual; New York Department of Transportation: Albany, NY, USA, 2017.

20. Bridge Design Manual; Washington State Department of Transportation: Olympia, WA, USA, 2017.

21. Bridge Manual; Wisconsin Department of Transportation: Madison, WI, USA, 2017. 